\title{
ORGANIZATION DESIGN FOR SUPPLIER ENGAGEMENT IN SUSTAINABILITY PROGRAMS: A FIELD EXPERIMENT OF ENABLING VS. COERCIVE FORMALIZATION
}

\author{
Franz Wohlgezogen*, University of Melbourne (fwohlgezogen@unimelb.edu.au) \\ Joerg S. Hofstetter, KEDGE Business School (joerg.hofstetter@kedgebs.com) \\ Frank Brück, University of Stellenbosch Business School \\ (frank.brueck@foundationgolden.org) \\ Ralph Hamann, University of Cape Town (ralph.hamann@gsb.uct.ac.za) \\ *Corresponding author
}

\begin{abstract}
Formal, compliance-focused governance for supply chain sustainability initiatives has a mixed empirical track record. We build on classic research on bureaucracy to examine how 'enabling' and 'coercive' formalization at the buyer-supplier interface affect attitudes, an important precursor to behavioral engagement. We conduct a randomized field experiment with the supplier community of a South African insurance company to directly compare treatment effects of enabling and coercive interventions. We report and discuss the enabling intervention's positive attitudinal effects and the moderation of these effects by supplier characteristics. We also discuss some notable null-effects, especially from the coercive intervention. We believe this work contributes to a more nuanced understanding of formal governance choices in supply chains and their impact on supplier engagement.
\end{abstract}

Acknowledgements: The authors are thankful to Federica DiStefano, and Clint Bartlett for their research support and insightful comments for early versions of the manuscript. 
Organization Design and Supplier Engagement in Sustainability Programs

\section{INTRODUCTION}

There is broad consensus in sustainable supply chain management research that corporations need to extend sustainability programs to their suppliers to significantly improve sustainability outcomes (Govindan, Seuring, Zhu, \& Azevedo, 2016; Seuring \& Müller, 2008). Increasing public awareness about corporations' direct and indirect impact on society and the environment, and stricter reporting regulations create external pressure on corporations to make transparent their active promotion of sustainable practices in their supply chains. While the objective of engaging suppliers in sustainability efforts, of 'shaking' them out of complacency (Sulkowski, Edwards, \& Freeman, 2018), is clear and urgent, it is less clear how firms can affect this shake-up. As Zollo, Cennamo and Neumann point out, promoting such a transformation towards sustainable business is challenging because it "touches not only $[\ldots]$ operating routines but also all the 'quasi-genetic' traits of the organization, from its strategies to its systems, from its cultural traits to its shared values and emotional dispositions" (2013:253).

A particularly vigorous scholarly debate has emerged over the role formal governance mechanisms play in the transformation towards sustainable business. Formal governance provisions, which stipulate the responsibilities and obligations of actors in an organization or in an exchange relationship, are widely utilized to manage supply chain sustainability: firms typically define codes of conduct for their suppliers, and they implement formal mechanisms for supplier monitoring, reporting and auditing (Formentini \& Taticchi, 2016). These administrative provisions de-facto broaden suppliers' formal, contractual roles in the supply chain to include sustainability considerations, and they make compliance with these role requirements mandatory. The United Nations Global Compact's guide for supply chain 
sustainability suggests that these formal mechanisms serve an important awarenessraising and expectation-setting step on the path to "deeper engagement" behavior by buyers and suppliers (Sisco, Chorn, \& Pruzan-Jorgensen, 2015). Indeed some empirical studies suggest that formal assessment systems can benefit collaboration (Gimenez \& Sierra, 2013; Large \& Thomsen, 2011; Sancha, Gimenez, \& Sierra, 2016a) and that compliance pressure can, over time, catalyze transformation of business practices (Egels-Zandén, 2014).

Critics of compliance-focused sustainability management approaches point to the exiguous progress that has been made after more than two decades of compliance monitoring (Labowitz \& Baumann-Pauly, 2014). Scholars have argued that compliance-based systems generate insufficient incentives for behavior change and set inappropriate relational norms to support remedial action and continuous improvement (Locke, Amengual, \& Mangla, 2009; Locke, Qin, \& Brause, 2007). Suppliers struggling with expanded role requirements frequently exploit information asymmetries by mispresenting or hiding problematic practices to achieve 'compliance' (Labowitz \& Baumann-Pauly, 2014; Plambeck \& Taylor, 2015). Such tensions and problems at the buyer-supplier interface erode trust in the supply chain and jeopardize the relational foundation for joint efforts in the future (Vurro, Russo, \& Perrini, 2009; Yu, 2008) ${ }^{1}$.

Reconciling these two opposing views has proven challenging, not least because extant empirical studies frequently struggle with differentiating varieties of formal governance practices and with specifying mechanisms through which these practices enable or inhibit supplier engagement and supply chain collaboration

\footnotetext{
${ }^{1}$ This research domain mirrors a broader inquiry in organization theory and strategy scholarship into the relationship between formal contracting and relational governance (e.g. Poppo \& Zenger, 2002; Puranam \& Vanneste, 2009; Cao \& Lumineau, 2015)
} 
(Vanneste, Puranam, \& Kretschmer, 2014). ${ }^{2}$ In addition, causal identification remains a problem due to the methodological predominance of cross-sectional designs that measure independent and dependent variables with a single survey, and case studies whose induced causal explanations are rarely tested in replication studies (Delmas \& Aragon-Correa, 2016; Van Weele \& Van Raaij, 2014).

The present study seeks to address these shortcomings, by (1) carefully distinguishing two alternative formal approaches to supplier relationship management, (2) articulating the mechanism by which they influence supplier engagement and behavior, and (3) testing the relative effectiveness of these approaches with a field experiment. Specifically, we build on the conceptual differentiation of 'coercive' and 'enabling' types of formalization (Adler, 1999; Adler \& Borys, 1996) to identify specific relational practices and their impact on supplier personnel attitudes, i.e. individuals' summary evaluations of administrative systems, goals, and the buyer-supplier relationship. Attitudes matter for supplier engagement because they shape how individuals perceive opportunities for positive change in the supply chain and how they invest themselves in the hard work of transforming business practices (Lülfs \& Hahn, 2014). In short: attitudinal change is often an important precursor to behavioral change.

To explain the mechanisms that underlie the attitudinal effects of alternative types of formalization, we apply insights from research on employee engagement to the supply chain context (Gruman \& Saks, 2011; Macey \& Schneider, 2008; Saks, 2006). This line of research provides an integrative conception of how attributes of

\footnotetext{
${ }^{2}$ However, see Amengual, Distelhorst, \& Tobin (2019) for a recent and effective effort to 'unbundle' formal governance activities to advance a more nuanced understanding of governance options and their effects.
} 
formal organization can activate employees' traits, psychological states, and behaviors.

Our randomized field experiment with a South African insurance company's supplier pool allows us to tackle the empirical challenge of isolating the causal effect of a specific formal organization design intervention in a complex (inter)organizational context. Originally conceived as a pilot project for identifying effective practices for catalyzing behavioral change towards sustainability in the firm's supply chain, the present study reports the attitudinal effects of the intervention.

The insurance industry context of our study provides us with a unique research opportunity. Sustainability management in the insurance industry is at an early stage of maturity ${ }^{3}$, and large groups of un-tiered small and medium-sized suppliers render individualized, "hands-on" developmental alliances and partnerships unfeasible to drive transformation at scale. Hence, our field experiment shows the effects of coercive and enabling formalization as an early-stage, broad-based engagement intervention to initiate, via attitudinal effects, change to suppliers' 'quasi-genetic' and cultural traits and thus provide a foundation for open communication and committed collaboration.

To our knowledge, the present study also constitutes the first attempt to test Adler and Borys' (1996) theory in a supply chain setting. Our findings support some of the 1996 study's predictions regarding the attitudinal benefits of enabling formalization, and regarding moderators for the attitudinal effects. However, we also

\footnotetext{
3 The UNEP Finance Initiative's Principles for Sustainable Insurance, a major effort to catalyze sustainable practices in the industry, were launched in 2012.
} 
find that attitudes regarding the buyer-supplier relationship are less malleable in the short-term than predicted. These insights shed light on formidable hurdles in the path of sustainable business transformation (Amengual, Distelhorst, \& Tobin, 2019; Zollo et al., 2013). We conclude the paper with a discussion of the conceptual ramifications and the limitations of our study, and we suggest opportunities for future research.

\section{THEORETICAL BACKGROUND AND HYPOTHESES}

\section{Bureaucracy, Formalization and the Supply Chain}

The study of formal governance mechanisms is historically closely associated with the study of bureaucracy. In Williamson's (1975) formulation of markets and hierarchies as alternative modes of governance, hierarchies essentially represent the bureaucratic organizational form, which is characterized by a fixed hierarchy of positions with contractually codified authority, jurisdiction, and duties; rules and procedures for the exercise of the positions' authority and fulfilment of duties; and comprehensive documentation of actions and decisions in central files (Parsons, 1947; Udy, 1959). Bureaucratic formalization pulls an organization towards standardization to manage organizational complexity and to facilitate coordination and control (Francis \& Stone, 1956; Hall \& Tittle, 1966; Mintzberg, 1980). A key enabler for coordination and control is the standardized system of information exchange: individuals within the organization gather and transmit information in compliance with prespecified procedures and requirements, such as regularly scheduled reports with standardized content. Bureaucratic structures' standardized information systems increase an organization's information processing capacity (Galbraith, 1974). While bureaucracies diminish the intensity of incentives, they do shape behavior by directing attention and effort towards activities and outcomes that get measured and reported (Ocasio \& Wohlgezogen, 2010; Ouchi, 1979). 
While the bureaucratic form has been conceived at the organizational level of analysis in its original formulation, aspects of bureaucratic arrangements are common also in interorganizational relations (Albers, Wohlgezogen, \& Zajac, 2016; Reuer \& Devarakonda, 2016). Supply chain management, in particular, relies on formalized roles, rules and procedures to enable efficient coordination of operational processes (e.g. synchronized planning, and control, e.g. buyers conducting audits of supplier conduct and performance, across a large number of involved firms).

Firm seeking to manage sustainability in their supply chain frequently apply bureaucratic, formal design interventions similar to those used to manage operations. Buyer firms typically specify supplier sustainability codes of conduct and mandate that suppliers regularly report their sustainability performance accordingly (Gualandris, Klassen, Vachon, \& Kalchschmidt, 2015; Parmigiani, Klassen, \& Russo, 2011; Wilding, Wagner, Pilbeam, Alvarez, \& Wilson, 2012). Codes of conduct for suppliers in a supply chain function as the equivalent of the specified authority, jurisdiction, and duties of a position in a bureaucracy: they aim to compel actors to alter practices to achieve compliance. Supplier sustainability self-reports are the interorganizational equivalent of traditional bureaucracies' 'paper trail' and constitute an accountability mechanism. Typically, firms verify the integrity of the reports through supplier audits. This formal approach of codifying sustainability practices and outcomes, standardized reporting, and systematic auditing provide the formal organizational backbone for sustainability management in many supply chains (Formentini \& Taticchi, 2016). Whenever the effectiveness of this bureaucratic approach to sustainability management was criticized, the issues largely mirrored overall concerns with bureaucratic organizing: instead of engaging in substantive change, actors tend to decouple practices from formal requirements; formal designs 
Organization Design and Supplier Engagement in Sustainability Programs

and centralized design authority lead to rigidity and inability to respond to emergent contingencies; and the emphasis on compliance stifles local initiatives for improvement (Argyris, 1957; Burns \& Stalker, 1961; Meyer \& Rowan, 1977).

\section{Bureaucracy and Engagement}

Many concerns about the effectiveness of bureaucratic structures are rooted in views about formal structure's social-psychological effects. Scholarship on bureaucracy particularly emphasizes its negative effects on organizational members' attitudes. Attitudes are defined as an actor's summary evaluations of an object that have affective, cognitive, and behavioral components (Petty, Wegener, \& Fabrigar, 1997). In the case of bureaucracy, attitudinal effects concern how organizational members think and feel about - and involve themselves with - their work and about the organization in which they are situated. Numerous studies document how bureaucracies spur members' feelings of alienation from their work (Argyris, 1957; Matheson, 2007; Miller, 1967), attitudinal issues that are commonly associated with low employee engagement in contemporary behavioral research (Gruman \& Saks, 2011; Kahn, 1990). Low engagement is associated with low personal involvement, commitment, motivation and identification with the work, resulting in organizational members performing tasks with minimum effort, and rendering supervisors' coercive attempts to generate greater effort ineffective.

Low engagement is particularly problematic in the context of supply chain sustainability efforts. Given the complexity of the transformation towards sustainable business practices, supply chain sustainability requires all partners' initiative and creative problem-solving capabilities and a commitment to iterative, continuous improvements (Amengual et al., 2019; Lowitt, 2013; Zollo et al., 2013). This vastly expanded role concept calls for a high level of supplier engagement. Suppliers, their 
managers and employees are called to invest their 'full selves', physically, cognitively, and emotionally in the task (Kahn, 1990). Without supplier engagement, without their willingness to invest and actively contribute to sustainability efforts, redefinition of buyer-supplier relationships around collaboration rather than fiat and (limited) compliance is unlikely to occur (Gulati, Wohlgezogen, \& Zhelyazkov, 2012). Given these demands, sustainability scholarship has begun to examine a broader set of collaborative practices at the buyer-supplier interface (Formentini \& Taticchi, 2016; Gimenez \& Sierra, 2013).

Yet, organizational scholarship suggests that some types of formal, bureaucratic arrangements can aid engagement. For example, Gouldner suggests that bureaucracies do not necessarily or exclusively represent 'disembodied forces' of oppressive conformity (1954:16). Instead, efforts to formalize and stabilize organizational practices can bring together managers and workers to develop 'representative rules' with the intent to assist problem prevention and resolution - a stark contrast to punishment-centered rules that are imposed on workers without their consultation or input.

The work by Adler and Borys (Adler, 1999; Adler \& Borys, 1996) represents a most notable revitalization of conceptual interest in such non-punitive formal organizational design. The authors suggest a distinction between two types of formalization, coercive and enabling, that have "very different effects on the organization and the people working in it" (Adler 1999:38). In short, coercive formalization cultivates compliance and rigidity and has a restrictive, de-skilling, disempowering effect on organizational members - much like Gouldner's (1954) pattern of punishment-centered bureaucracy. Enabling formalization fosters learning, innovation, flexibility, and collaboration. 
Research on employee engagement addresses concerns similar to those discussed in Adler and Borys' 1996 study, namely the organizational antecedents that shape "how individuals employ themselves in the performance of their job" (Saks, 2006:602). Macey and Schneider (2008) suggest a conceptual model of employee engagement, in which organization design attributes shape psychological state engagement, i.e. employees' feelings of involvement, empowerment, energy etc., which in turn predict behavioral engagement such as personal initiative and adaptive behaviors. This model is compatible with Adler and Borys' view that "distinctive features" (1996:67) of enabling and coercive formalization shape employee attitudes, which in turn influence how employees behave in their formal roles. Below we use this conceptual model of employee engagement as a foundation for our hypothesis development.

By carefully translating bureaucracy and employee engagement research from the organizational to the interorganizational level, we follow other studies which have shown that concepts traditionally used in the intra-organizational context can usefully be applied to understand dynamics of inter-organizational or meta-organizational systems (Albers et al., 2016; Dyer, 2000; Gulati, Puranam, \& Tushman, 2012). Specifically, we hypothesize how coercive and enabling formalization affects supplier personnel's attitudes to (1) the administrative system that connects them with the buyer, (2) sustainability goals that are served by that administrative system, and (3) the buyer-supplier relationship itself. For these attitudinal effects, we also test two potential contingency factors that have been suggested by Adler and Borys (1996). The causal model depicted in Figure 1 provides an overview of our hypotheses. 
Organization Design and Supplier Engagement in Sustainability Programs

\section{Attitudes towards administrative systems}

Actors' perception of the administrative systems that define their work environment can influence their engagement (Macey \& Schneider, 2008). For example, recent global employee surveys reveal that role clarity, the clear definition of responsibilities, is a key correlate of employee engagement (Rigoni \& Nelson, 2016). At the same time, numerous studies of bureaucracies in public and private sector organizations show that formal structures that are perceived as severely limiting individual agency and curtailing professional judgement fuel disengagement (Argyris, 1957; Matheson, 2007).

Adler and Borys (1996) characterize coercive bureaucracy as seeking compliance behaviors, where formalization serves as a basis for disciplinary intervention in case of deviations from rules and procedures. It discourages organizational members from questioning rules and procedures, and from contributing ideas for potential improvements. In such systems of organization, in which structures become strictures - the metaphorical "iron cage" Max Weber foreshadowed in his work - actors perceive the administrative system as hindering rather than supporting productive work. Because such administrative systems curtail autonomy and judgement, they reduce experiential learning opportunities for employees, which can ultimately lead to de-skilling. More immediately, it fosters employees' feelings of exclusion and disempowerment, making active behavioral engagement less likely.

In contrast, enabling formalization aims to "support the work of the doers rather than to bolster the authority of the higher-ups" (Adler 1999:38). It does so by capturing organizational experience by accumulating and diffusing 'good practice' and tried-and-tested routines. Formalization thus aims to facilitate up-skilling, so that employees understand better the 'how' and 'why' of work and can deal with 
difficulties and dilemmas more effectively and efficiently. It invites and values rather than suppresses professional judgement that may lead to deviations from rules and procedures. This degree of flexibility and legibility renders enabling formalization to be "experienced by employees as a tool with which they can better perform that tasks rather than a weapon used by their superiors against them" (Adler 1999:38). In a supply chain context, enabling bureaucracy would provide suppliers with guidelines that represent 'good practice' but simultaneously invite utilization of knowledge, experience, and abilities. This psychological state engagement, where the administrative system is seen as promoting involvement and empowerment, make behavioral engagement, e.g. personal initiative and adaptive behaviors more likely.

Hence, we hypothesize:

Hla: Enabling (coercive) formalization will increase (decrease) attitudes to the administrative system as a supportive resource that aids the supplier's task performance.

H1b: Coercive (enabling) formalization will increase (decrease) attitudes to the administrative system as an instrument of control over the supplier's task performance.

\section{Attitudes towards goals}

Formalization of organizational activities requires considerable effort (Ouchi, 1979) and thus signals the importance of formalized activities. However, fixed standards of performance, and rigid rules and procedures that are characteristic of coercive formalization also suggest a disinterest in exploring opportunities for improvement. In a supply chain context, sustainability management approaches that rely on rigid rules and procedures and compliance audits define narrow roles for 
suppliers, a minimum threshold of "good enough" performance, and imply that activities which go beyond these set limits are not required (Yu, 2008).

In addition, the deskilling effect of coercive formalization eliminates the possibility for suppliers to gain a deeper understanding of the underlying issues that bureaucratic provisions in the supply chain seek to address. In a coercive bureaucracy, rules and procedures are "formulated as lists of flat assertions of duties" (Adler \& Borys, 1996: 72). As research on employee engagement suggests, an understanding of organizational activities and goals as meaningful is an important determinant of individuals' willingness to invest themselves fully in their roles (Gruman \& Saks, 2011; Macey \& Schneider, 2008). Consequently, suppliers embedded in compliancefocused sustainability regimes develop only limited buy-in and commitment to sustainability improvement efforts.

In contrast, enabling bureaucracy emphasizes improvement. Rules and procedures are designed to help employees develop "mental models of the [organizational] system" that allow them to formulate and evaluate suggestions for system improvement (Adler \& Borys, 1996:70). In a supply chain, a buyer's commitment to upskilling suppliers through capacity building, and to developing collaborative capabilities across supply chain interfaces to develop and implement innovative practices and solutions to sustainability challenges, signals that the underlying issues are sufficiently important to warrant efforts that go beyond 'boxticking' to satisfy predefined rules and procedures.

Based on these arguments we hypothesize: 
Organization Design and Supplier Engagement in Sustainability Programs

H2: Enabling (coercive) formalization will increase (decrease) attitudes to the importance of goals for whose attainment formal systems have been designed.

\section{Attitudes towards relationships}

A crucial attitudinal consequence of bureaucratic systems is how they shape actors' construal of their relationships with others in the system. Adler and Borys (1996) suggest that coercive bureaucracies have a distinctive imprint on vertical relationships within an organization. They tend to amplify power differences between hierarchical ranks in an organization by removing autonomy from lower ranks, and by reserving the privilege to design and alter rules and procedures for higher ranks. The emphasis on discipline and punishment "to extract recalcitrant effort" (Adler \& Borys, 1996:69) betrays supervisors' lack of trust in employees' motives, and their belief that employees will respond opportunistically to any leeway granted or any chance offered to influence organization design. Adler and Borys note, that "under such a regime, $[\ldots]$ employees inevitably will reciprocate management's lack of trust" (1996:70). As a result, upward communication frequently dries up, and employees cease to share negative information or concerns with superiors. A similar pattern of guarded communication between suppliers and buyers has been documented in supply chains that rely on compliance-focused sustainability management regimes (Plambeck \& Taylor, 2015)

Unlike coercive bureaucracies, enabling bureaucracies advocate a shared power logic by giving some authority to employees to situationally deviate from for existing rules and procedures by encouraging involvement in their improvements. Adler and Borys suggest that such "participative design processes [create] a context much closer to the ideal speech situation $[\ldots]$ in which consensus is sought by rational 
Organization Design and Supplier Engagement in Sustainability Programs

argument, and participants acknowledge the right of each to participate in the dialogue as autonomous and equal partners" (1996:82).

Importantly, enabling bureaucracies' participative approach expresses capability-based trust as it recognizes and values organizational members' experiential knowledge and skill. This appreciation encourages members to actively engage in collaborative opportunities because they can expect that contributions are received with consideration. In supply chains, such a capability-based trust approach is exemplified by knowledge sharing provisions in supplier networks (Dyer \& Nobeoka, 2000) and consultative sustainability planning efforts (Keating, Quazi, Kriz, \& Coltman, 2008; Parmigiani et al., 2011).

In sum, enabling formalization in these contexts can foster a collaborative relationship concept, elevating suppliers to become engaged co-designers of the supply chain's sustainability management system - even in the absence of a formal strategic alliance or partnership agreement.

H3: Enabling ('coercive') formalization will increase (decrease) attitudes to the buyer-supplier relationship as collaborative.

\section{Contextual contingencies}

Adler and Borys (1996) recognize a number of organizational contextual factors that affect the purported relative advantages of enabling formalization over coercive formalization. Specifically, they point to the congruence between organizational goals and employees goals as a 'critical contingency' for enabling formalization to work. When this congruence exists "employees no longer experience formal procedures for routine work as a negation of individual autonomy but as a valuable means to a desired end"; but when employee and organizational goals are 
incongruent "the enabling type of formalization is unavailable" (Adler \& Borys, 1996:80). Translated to the supply chain context, this suggests that even when buyers establish enabling formalization to invite suppliers to invest themselves in a collaborative supply chain initiative, suppliers' employees will not experience positive state or behavioral engagement if they do not identify with the goals of the initiative.

In addition, Adler and Borys note that only when employees have the "appropriate training and resources, employee involvement in the formulation of procedures is likely to have a positive effect on both attitudinal and technical outcomes" (1996:74). Indeed, an important influence for effectiveness of attitude change via high-effort processes - such as carefully considering and reporting on organizational practices in the context of a formal procedure - is individuals' expectation whether the attitude object (e.g. the administrative system) is associated with positive consequences, e.g. the ability to solve problems. Organizational members who anticipate negative consequences from enabling bureaucracy, because they feel ill-equipped to act competently and/or effectively in it, are unlike to experience positive attitudinal change (Petty et al., 1997). This logic provides an attitudinal mechanism that explains why supplier capability is a critical bottleneck for meaningful supply chain sustainability improvements (Amui, Jabbour, de Sousa Jabbour, \& Kannan, 2017; Correia, Carvalho, Azevedo, \& Govindan, 2017). In short, only suppliers whose personnel believes that their organization has suitable capabilities to effectively operate in an enabling bureaucracy will experience positive state and behavioral engagement from an enabling formalization intervention.

H4: A supplier's level of goal congruence with a buyer moderates the hypothesized effects of enabling (coercive) formalization on the supplier's 
Organization Design and Supplier Engagement in Sustainability Programs

attitudes towards administrative systems, goals, and the buyer-supplier relationship.

H5: A supplier's level of relevant organizational capabilities moderates the hypothesized effects of enabling (coercive) formalization on the supplier's attitudes towards administrative systems, goals, and the buyer-supplier relationship.

\section{METHODOLOGY}

\section{Empirical Setting}

We investigated the effect of coercive and enabling formalization on supplier engagement with one of the largest South African insurance companies. The firm had identified rising systemic risk and vulnerability for its business due to a variety of environmental, social, and governance issues, and consequently introduced sustainability as a key management concern. As a response, its CEO established a sustainability task force within the corporate strategy department, which was given responsibility for formulating the firm's sustainability strategy and designing and overseeing strategic initiatives.

In 2013, an audit to identify priority areas for sustainability initiatives revealed that despite the company's low environmental impact from internal operations, its indirect impact on the environment through its suppliers was substantial. It applied especially in the car insurance domain, where the firm manages a portfolio of about 3,000 car repair services suppliers, of which approximately 1,100 are motor body repair (MBR) service providers. Because repair work on vehicle bodies involves substantial material recycling opportunities (e.g. the replaced bumpers, doors, glass, etc.), and requires safe material handling practices (e.g. of oil, paints, etc.), MBR 
Organization Design and Supplier Engagement in Sustainability Programs

suppliers were identified as a priority target for engagement in sustainability initiatives and became the focus of our study.

The insurance company's business relationships with MBR suppliers have traditionally been arm's-length and transactional. Beyond regular business transactions, the insurer had little interaction through training or other supplier development activities with the suppliers. The ex-ante formalization of the relationship was minimal, based on standardized contracts that specified service level requirements which included some limited environmental standards. A senior representative of the firm's procurement department described the buyer-supplier relationships as a "battlefield", characterized by ongoing conflict over pricing, and allocation of the insurer's business volume and ensuring regional availability of suppliers' service capacity. Some supplier assessment was undertaken based on customer satisfaction scores, but no systematic monitoring or auditing procedures were in place to ensure supplier compliance. This relatively 'clean slate' provided a suitable context to examine the effects of the introduction of alternative types of formalization for environmental sustainability practices.

\section{Intervention Design Process and Sample}

Following an engaged scholarship approach (Van de Ven, 2007), we developed the field experiment for the supplier community in close collaboration with representatives from the firm's procurement, sustainability, and strategy departments. The firm's stakeholders were interested in adopting a field experimental approach which they had not used previously - to be able to better evaluate the impact of implemented initiatives.

Initial interviews with internal stakeholders revealed a shared interest in 
understanding supplier personnel's attitudes towards environmentally sustainable practices in the supply chain, and in exploring interventions for influencing attitudes as a first step towards boosting supplier engagement in environmental sustainability initiatives. To verify the environmental issues that the firm's internal stakeholders had articulated as most relevant for the MBR industry, we interviewed representatives from a diverse sample of four MBR firms, and representatives from two South African industry associations (SAMBRA and CRA). These interviews and a final consultation with the firm's internal stakeholders yielded a list of five environmental issues to focus on: energy usage, water consumption, liquid waste, solid waste, and air pollution.

We developed a reporting procedure intervention which randomly assigned participants to three conditions $(\mathrm{C} 0, \mathrm{C} 1$, and $\mathrm{C} 2)$ that manipulated the specific features of the procedure according to the characteristics of enabling and coercive formalization (and business-as-usual in a control group). This constituted a simple and low-cost intervention which suited the insurance firm's resource constraints and its desire to minimize disruptions to its own and its suppliers' operations. Adler and Borys (1996) suggest that coercive and enabling bureaucracies differ with regards to their design features (rigid procedures vs. flexible guidelines), design process (topdown imposed vs. co-developed), and their implementation context (managers and norms restricting vs. allowing for flexibility). Our empirical context allowed us to incorporate aspects of the first two dimensions - design features and process - into the alternative reporting procedure formats. In essence, the reporting procedures are a communication-based intervention, which is common for field experiments in organizational or interorganizational settings (Chatterji, Findley, Jensen, Meier, \& Nielson, 2016). 
With the insurance firm we planned a phased evaluation of the effectiveness of the interventions. The first phase, reported in the present study, evaluated the effect of coercive and enabling formalization on suppliers' attitudes via a pre-post questionnaire (see details in the two following sections). The second phase, as of yet not implemented, would assess behavioral changes through a combination of a supplier self-reports on sustainability practices and 'on the ground' impact case studies with a sample of suppliers.

We note that, by using alternative versions of a reporting procedure as the experimental treatment, our research design shares some characteristics with survey experiments or 'framed experiments', which provide field context to participants abstractly through task instructions or briefing documents (Harrison \& List, 2004; Nock \& Guterbock, 2010). In contrast, 'natural' randomized field experiments engage subjects in the environment where they would naturally undertake the required tasks (Delmas \& Aragon-Correa, 2016). ${ }^{4}$ In our study, the online reporting forms we designed represented to the participating suppliers an 'actual', new formal governance mechanism for the reporting of environmental sustainability-related information - a mechanism that was embedded in a complex, ongoing business relationship. This materiality of the intervention qualifies our method as a natural field experiment in (inter)organizational design.

\section{Experimental Protocol}

All participants at time $t=0$ filled out a short baseline survey containing Likert-type and rank order-type questions about their views on the role of formal rules

${ }^{4}$ These controlled experiments are not to be confused with quasi-experiments, also referred to as 'natural experiments', in which the intervention and assignment to experimental conditions is not controlled or manipulated by researchers. 
and procedures in the supply chain, the importance of environmental sustainability issues for the supplier and the buyer, the buyer-supplier relationship, and some parameters of the supplier's operations (an overview of the survey items is presented in Table 1, measures are described below in the next section). Participants in the control group $(\mathrm{C} 0)$ received only this attitudes survey.

Respondents in the first treatment group (C1) were additionally asked to respond to 13 questions about specific environmental practices and issues in their firm and the MBR industry (see Appendix 2), as part of the survey. The questions were posed in an open-ended format, designed to prompt suppliers to reflect on their environmental practices, and to give them substantial freedom to decide what information to report. Specifically, the questionnaire asked what suppliers perceive as the most important environmental issues, how they assess their own environmental performance vis-à-vis competitors, where they see improvement opportunities, how they would implement such improvements, and what they consider major hurdles for improving environmental performance in their organizations. The purpose of these questions was explained to respondents as eliciting "your views and suggestions on environmental issues and practices in the MBR industry, and in your company". This reporting format serves as the enabling bureaucracy intervention, as it provides a flexible thematic orientation to suppliers, and invites them to raise issues they consider important.

A second treatment group (C2) also received 13 questions about specific environmental practices in their firm following the attitudes survey, but the questions for this group were presented in a multiple-choice format, or in a format that required specific numerical responses (see Appendix 3). The purpose of these questions was explained to respondents as "focusing suppliers on specific categories of 
environmental impact: energy usage, water consumption, liquid waste, solid waste, and air pollution" and to "record your company's current environmental practices in these categories." This reporting format served as the coercive bureaucracy intervention, given its pre-defined categories and formats, implied performance expectations, and lack of opportunity for suppliers to introduce additional or divergent issues.

Three months later (time $t=1$ ), all respondents to the initial survey were invited to a follow-up survey, which contained the same questions as the baseline attitudes survey and thus allowed the assessment of the two treatments' attitudinal effects.

$========$ insert Table 1 about here

\section{Measures}

Dependent variables. We empirically examined the effect of the treatments described above on participating supplier personnel's responses to the attitude survey (see table 1). Item 1, relating to benefits of the administrative system (hypothesis 1a and 1b), is based on Adler and Borys' (1996) characterization of enabling and coercive formalization design features. To tease out what respondents view as the primary benefit of rules and procedures, we formatted the item as a forced rank order question. Responses that ranked learning and problem-solving most highly indicate attitudes to the administrative system as a tool that support the supplier's task performance. Responses that ranked control and alignment most highly indicate attitudes to the administrative system as a mechanism for control over the supplier's task performance. We created dummy variables for each of the item's four response options, coded as 1 if the option was ranked highest, and coded 0 otherwise. 
To measure supplier personnel's attitude towards the importance of goals for which the formal governance mechanism was introduced (hypothesis 2), we included two 7-point Likert-scale items (items 2 and 3) focused on the value of sustainability for the insurance firm and the importance of sustainability for the firm's success.

The survey items characterizing the buyer-supplier relationship (items 4-7) were based on Sancha et al. (2016a) and Temby, Sandall, Cooksey, and Hickey (2017), and adapted to suit our empirical context and the insurer's requirement for survey brevity. In contrast to item 1 , these survey items refer explicitly to the insurance firm, using the firm's name. We regarded responses to items 4 and 5, regarding mutual trust and the supplier's ability to bring up problems with the insurer, as indications of a collaborative relationship, and responses to items 6 and 7, regarding the insurer requiring operation reporting from the supplier and formal evaluation of the supplier, as indications of a non-collaborative, hierarchical relationship.

Moderators. In line with the theorization of potential moderators of the effectiveness of coercive and enabling formalization in Adler and Borys (1996), we measured goal congruence and supplier capability. We conceptualize goal congruence for the supply chain environmental sustainability initiative as the alignment between buyer and supplier on the importance of environmental sustainability. Since the buyer held the issue as a strategic priority, buyer-supplier goal congruence would be high if the supplier also regarded the issue as highly important, and would be low if it did not. Accordingly, we included a prompt about the importance of environmental sustainability for the supplier (item 8) in the survey. We coded suppliers whose responses were above the mean index value as 'high congruence', and those whose responses were below the mean index value as 'low 
congruence', for a split-sample moderation test. ${ }^{5}$

We measured a supplier's capability based on its OEM certifications. OEM certification is an industry requirement for suppliers to be able to conduct repairs on vehicles under manufacturer warranty. To receive the certification, suppliers need to comply with detailed operational and environmental standards mandated by car manufacturers, and need to pass surprise audits to retain the certification. OEMs' requirements differ and satisfying the requirements generally requires substantial investment in equipment. Hence, the number of certificates a supplier has retained is used as a signal of service quality in the MBR market. Our survey item for OEM certification offered suppliers three response options - none, one, or multiple - to proxy low, medium, and high supplier capability. However, only 5\% of suppliers reported having only one OEM certificate. Hence, we again adopted a split-sample moderation approach, using the subsample of suppliers with no certificate and those with multiple certificates as the low and high capability groups respectively.

Controls. In order to assess potential causes for bias, we also included questions in the baseline and follow-up survey on additional factors likely to influence suppliers' response to the treatments. Firm size (survey item 10), measured as the number of cars repaired per year by the supplier firm, provides a proxy for the scale and complexity of operations which may favorably affect the suppliers' response to enabling bureaucracy interventions (Adler \& Borys, 1996:83). Lastly, a supplier's readiness for change may render it less responsive to the treatments and shape attitudes regarding the feasibility and likely outcomes of any change efforts in

\footnotetext{
5 To ensure robustness of results to alternative model specifications, we also ran analyses in which we used the top and bottom quartiles of the congruence index variable to identify high and low goal congruence suppliers. This alternative specification results in a lower number of firms in the subgroups, and lower statistical power. The pattern of results remains consistent, however.
} 
the supply chain, sustainability-related or not. We assessed readiness for change with Likert-scale response to survey items 11 to 13, adapted from Cunningham, Woodward, Shannon, MacIntosh, Lendrum, Rosenbloom et al. (2002). Since all three items were highly correlated, we collapsed them into a single factor.

\section{Pre-study}

The intervention was tested with a regional subset of the insurer's supplier base. This test was vital given the novelty of our treatment. We also needed to ensure that the wording of the treatment resonated with participants, many of whom would not have received any formal management training or college education. A pilot version of the attitude survey was emailed by the company to 200 suppliers from the Western Cape region. The 36 suppliers who responded to the survey were invited to participate in a half-day, face-to-face workshop at the insurance firm's headquarters. Ultimately, 25 suppliers attended the workshop. After a short series of presentations about the company's sustainability agenda and initiatives, the attending supplier representatives were assigned to two separate groups to fill-out and openly discuss the coercive and enabling version of environmental practices questionnaire, respectively. A short survey after the group discussions confirmed that managers perceived the two formalization interventions as distinctive and congruent with our intentions: the enabling formalization questionnaire's items were evaluated as more open, flexible, and participative, and the coercive formalization items as more restrictive, rigid, and directive.

\section{Non-response bias}

The invitation to 900 suppliers to voluntarily participate in the baseline survey, issued by the insurance firm, resulted in 232 complete responses $(26 \%$ response rate). The firms who completed the baseline survey were subsequently 
contacted for the follow-up survey, resulting in 113 complete responses $(51 \%$ attrition rate). ${ }^{6}$

One of our main concerns was a sampling bias towards larger suppliers which would limit the usefulness of the study's findings for smaller suppliers, which in the MBR industry represent the biggest opportunity for reducing harmful environmental practices. Unfortunately, severe limitations in basic supplier data (e.g. supplier size/revenue, length of their contractual relationship, performance) available to the insurance firm, and our limited direct access to suppliers for inquiries posed challenges in assessing differences between our sample and the rest of the population.

We tried to overcome these challenges to identifying potential sampling bias with a combination of steps. First, we drew on qualitative data we collected during our stakeholder interviews with procurement personnel and suppliers. Given their characterization of the MBR supplier market as mostly comprised of small firms with a business volume of less than 500 vehicles repaired per year and no OEM certification, our sample was skewed towards larger, high capability suppliers: only $23 \%$ of the survey respondents report less 500 vehicles repaired per year, and $30 \%$ of respondents indicated that they had no OEM badges. While our sample underrepresents small suppliers, it still provides a range of supplier sizes (from 60 to 3600 cars per year). The low number of non-OEM certified suppliers participating in both surveys makes it difficult to draw firm conclusions from the analysis for this supplier subgroup.

In addition, we examined differences between suppliers who had responded to

\footnotetext{
${ }^{6}$ Eight additional, complete responses were received, but had to be removed since they were provided by a different individual than those from the baseline survey, thus rendering the experimental manipulation ineffective.
} 
the follow-up survey before the deadline and those 38 firms that responded after being randomly selected from non-responders for an individualized follow-up telephone call by a representative of the insurance firm. While these 'late responder' supplier firms are not technically non-responders since they ultimately completed the follow-up survey, the procedure through which they were contacted is equivalent to typical outreach efforts to non-responders in comparable studies (see e.g. Zaheer, McEvily, \& Perrone, 1998) and thus offers some insight into non-responder firm characteristics.

We did not find significant differences between late-responders and regular responders in the means of firm size or the proportion of OEM certifications.

\section{Analytical strategy}

We identified the treatment effects of our alternative interventions using the differences-in-differences (DID) method, which compares the differences in outcomes before an intervention $(t=0)$ and after an intervention $(t=1)$ and for groups affected by that intervention $(D=1)$ to the difference of the same outcomes for a group unaffected by the intervention $(D=0)$, expressed formally as:

$$
\delta=\left(y_{D=1, t=1}-y_{D=1, t=0}\right)-\left(y_{D=0, t=1}-y_{D=0, t=0}\right)
$$

Specifically, we used the DID approach to estimate the treatment effect of each formalization intervention compared to the control group $\left(\delta_{0-1}\right.$ and $\left.\delta_{0-2}\right)$. The DID approach is frequently used in field experiments and quasi-experiments for causal inference, especially in the context of policy and program evaluation. It addresses common omitted variable bias problems when estimating treatment effects (Card \& Krueger, 1994). This has substantial practical advantages for field experiments: the messy reality of field settings typically does not allow for comprehensive measurement of potentially confounding events occurring between 
baseline and follow-up measurements.

$=======$ insert Table 2 about here $========$

\section{RESULTS}

Table 3 presents the results from the DID analyses about the effect of our treatments on supplier personnel's attitudes. Models 1-5 show the results for the enabling formalization intervention, model 6-10 show the results for the coercive intervention. For both sets of models, we first present the interventions' effect on attitudes for the full sample of suppliers within the treatment group, and then present the split-samples for high and low goal congruence and for high and low organizational capabilities to examine the hypothesized moderating effects.

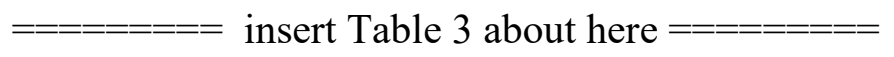

We find the strongest overall support for our prediction that enabling formalization fosters a stronger attitude to administrative systems as supportive rather than controlling (hypothesis 1a and 1b). Respondents were more likely to see learning as a primary benefit of rules and procedures, and that increased likelihood was amplified in the high capability subsample. Surprisingly, we find a significant negative effect of the enabling intervention on respondents' likelihood of regarding rules and procedures as primarily beneficial for problem solving. That negative effect is again amplified in the high capability subsample, but also in the high goal congruence subsample. Also counter to our predictions, the coercive intervention had no significant negative effect on the ranking of learning and problem solving as key benefits of rules and procedures, and provided no boost to the ranking of control and supervision of suppliers, or supply chain alignment as the main benefits. For the full sample (model 6) we instead find a negative effect on the likelihood that control and 
supervision are ranked as a primary benefit.

Our predictions regarding changes in attitudes to the value and importance of sustainability (hypothesis 2) receives partial support. The enabling intervention has strengthened attitudes somewhat, and that effect is amplified in the low goal congruence group and, to a lesser degree the low capability subsample. Counter to our expectations, the coercive formalization does not systematically weaken the attitude to sustainability as an important goal.

Lastly, we find little systematic support for our predictions regarding changes in attitudes to the buyer-supplier relationship. The only notable pattern of results is that following the coercive intervention respondents have a stronger view that the buyer mandates detailed operational reports. This pattern is particularly curious, given that (1) the enabling formalization reporting forms had one more question than the coercive formation form, (2) the open response format in the enabling formalization condition provided opportunity to communicate more detail than the coercive formalization report, and (3) the median time spent by study participants on completing the reporting form for the coercive formalization condition is actually 5 minutes lower than the median time participants spent completing the form for the enabling condition.

\section{DISCUSSION}

The present study has examined the effect of different approaches to the formalization of a supply chain environmental sustainability initiative on supplier personnel's attitudes. Drawing from research on bureaucracy and employee engagement, we predicted that 'enabling' formalization used to engage suppliers in sustainability efforts would have a positive effect on suppliers' perception of the 
benefits of formal arrangements, the importance of sustainability in their supply chain, and the quality buyer-supplier relationships, while a 'coercive' formalization would have a negative effect. In short, we expected that an enabling formalization intervention would trigger positive psychological state engagement that could serve as basis for behavioral engagement in supply chain sustainability initiatives, while coercive bureaucracy would foster psychological states that are detrimental to behavioral engagement.

The results from the field experiment provide some empirical support for the positive, engaging effects of enabling formalization. Particularly notable is the positive impact on suppliers' perception of the learning benefits of rules and procedures. Administrative systems' potential for enhancing understanding of the nature of a task and a task environment is a crucial foundation for bureaucracy's role in enabling constructive action (Adler \& Borys, 1996). This purported stimulus for learning and understanding is a significant departure from the common preconception of formalization as a mechanism for unquestioning, mindless compliance. It may encourage actors to pay close attention to details of a task and task environment, and may activate relevant experience and local, tacit knowledge. Assuming such a cognitive mechanism, we would expect actors with more relevant capabilities to invest into a business relationship to perceive relatively more learning benefits than others. And indeed, our empirical results suggest such contingencies: responses from suppliers with a high level of relevant competencies show a larger positive change in the perception of learning opportunities as the primary benefit of administrative systems. These learning-related attitudinal changes are particularly relevant in light of arguments regarding the benefits of knowledge development for supply chain 
sustainability (Raymond, Fazey, Reed, Stringer, Robinson, \& Evely, 2010; Zollo et al., 2013).

In theory, learning benefits for organizational members translate to improved problem-solving and continuous improvement. In Adler's words, enabling bureaucracy is "offering [workers] ideas on how to do their jobs more effectively." (Adler, 1999:43). Surprisingly, we found a negative attitudinal shift regarding formalization's problem-solving as a primary benefit as a result of the enabling bureaucracy intervention. These results may raise some concerns about the effectiveness of enabling bureaucracy for engaging suppliers in tackling sustainability problems. However, we propose a more optimistic and nuanced interpretation that considers more fully the specific empirical setting of our study.

The results can be attributed to respondents' relative unfamiliarity with enabling bureaucracy interventions. Given the prevalence of coercive, compliancefocused organizational and contractual arrangements in the motor-body repair industry and the insurance industry ${ }^{7}$, firms may have been habituated into believing in coercive formalization's necessity and effectiveness for problem solving. This interpretation receives some support from the finding that the high-capability, OEMcertified supplier group - the group most extensively subjected to coercive bureaucracy in the form of stringent certification requirements and surprise compliance audits - evidenced the most marked negative shift in attitudes regarding the problem-solving benefits of enabling formalization. Change of held assumptions and habits is likely to occur only slowly if at all. Indeed, some empirical evidence suggests that coercive bureaucratic structures can have lasting negative effects on

\footnotetext{
${ }^{7}$ Mintzberg (1980) used the insurance companies as a primary example of what he referred to as the 'machine bureaucracy' type of organizational - roughly equivalent to Adler \& Borys' (1996) coercive bureaucracy
} 
attitudes towards creative problem-solving, because they reduce exposure to creative opportunities, and suppress the development of relevant skills (Sorenson 2007). It seems plausible, then, that sustained exposure to coercive provisions has left suppliers numbed and dulled, and with an immune response that effectively rejects enabling bureaucracy - at least when it is experienced in the form of a subtle, one-off intervention like the one we tested. Consequently, suppliers may require repeated or more sustained exposure to enabling bureaucracy from the buyer, in order to overwhelm the immune response, and to 'infect' them with a mindset that embraces non-compliance-oriented collaborative relationships and joint-solving as a robust approach to the challenges of transforming their supply chain towards sustainable business practices.

We also note with interest that some attitudinal dimensions, particularly attitudes regarding the supplier's relationship with the buyer, remained unaffected by our manipulations. Admittedly, a single and subtle intervention - even though it was visibly endorsed by and linked to the buyer - may be insufficient to prompt suppliers to reconsider basic assumptions about the nature of their business relationships, such as the level of trust. Nevertheless, we were surprised to find no effects of the enabling formalization treatment on suppliers' perception of whether they could raise problems and tough issues with the focal firm given that the intervention instrument explicitly stated as its objective the elicitation of suppliers" "views and suggestions on environmental issues and practices" and given that the open format of the questionnaire items required them to state their views and opinions.

We interpret the relative obstinacy of supplier personnel's relationship-related attitudes in our study as an indication that suppliers may hesitate to fully engage in this communication channel that is opened by the enabling formalization reporting 
Organization Design and Supplier Engagement in Sustainability Programs

mechanism. By inviting suppliers to communicate openly about what they regard as important sustainability issues, the buyer is essentially asking suppliers to take the first step in transitioning from a hierarchical, compliance-focused relationship to a collaborative one. Suppliers, in turn, are likely waiting for a visible commitment from the buyer to the proposed relational redefinition. Such commitment could be demonstrated by sharing the knowledge gained through the reporting intervention with the supplier community, or to offer assistance to suppliers for tackling identified challenges. Locke and colleagues' study of Nike's supplier development efforts (Locke et al., 2007) shows that such relationship building requires a sustained demonstration of commitment. Our recent interactions with representatives of the buyer's procurement department revealed that approximately one year after the presentation of the present study's findings to the insurance firm, efforts had been made to adopt supplier relationship management practices consistent with the conception of enabling bureaucracy. Specifically, they reported that they had begun to remedy the infrequent direct contact with suppliers by implementing regular one-onone communication to support and consult suppliers. This can be regarded as a foundation for promoting supplier involvement, improving goal congruence, and enabling joint problem prevention and resolution in the pursuit of sustainability goals. Crucially, this approach signals a departure from the adversarial, "battlefield" approach to supplier relationship management that appeared widespread prior to our study, and suggests a behavioral change towards a more collaborative approach.

Lastly, we consider the null-effects of the coercive intervention to suggest that our treatment may not have been coercive enough. Indeed, we were unable to replicate in our field experiment one critical aspect of coercive formalization, namely the punishment of non-compliance. The null-effects can also be regarded as a sign 
that in a context that is already saturated with coercive formalization, as is the case for the MBR industry, an additional coercive formalization simply does not stand out. All in all, the pattern of null-effects in the coercive condition resonates with prior studies that found compliance-focused organizational provisions in buyer-supplier relationships to be ineffective for (positive) attitudinal change and engagement (Foerstl, Azadegan, Leppelt, \& Hartmann, 2015).

In sum, our study suggests that formalization, when designed prudently, can support engagement goals by fostering positive attitudes among suppliers' personnel. The concept of enabling bureaucracy gives useful impulses for those design choices, and in our field experiment yielded some encouraging short-term effects on attitudes.

\section{Limitations and Future Research}

Our study is characterized by limitations regarding the generalizability of findings that are typical for single-industry and single-firm (or more precisely: singlesupply chain) studies. It is possible that our empirical results are caused by the unique relationship history, business dynamics, and industry norms of our empirical setting. For example, the relative congruence or incongruence of an enabling or coercive intervention with the insurance firm's level and type of supplier engagement initiatives prior to our study period may influence the observed attitudinal changes and null-effects. Future research could replicate similar enabling and coercive bureaucracy interventions in different industry settings, or adopt study designs involving multiple buyer firms and their respective supplier portfolios, and measure those buyers' management styles, control systems, and historical supplier engagement programs to tease out potential moderating effects. This would contribute towards promising efforts to advance structural contingency theory for sustainable supply chain management (Sancha, Wong, \& Thomsen, 2016b). 
Organization Design and Supplier Engagement in Sustainability Programs

Ideally, future research would also seek multiple respondents for each involved supplier, to overcome the biases and limitations of single-response data collection that apply to our study. In our field experiment, the alternative formalization treatments affect only the individual who responded to the survey, which thus manipulates and measures only the attitudes of this organizational member. Whether that individual's attitudinal changes carry over to others in the organization is an open question and may depend on their role in the organization. At the very least, it constitutes a risky pathway for substantial behavioral change that future iterations of similar design intervention should look to improve.

We also note the limited number of measures about suppliers we were able to include in our study. This is particularly regrettable, given the variations in treatment effects we found with different supplier profiles (OEM certified vs. not OEMcertified) and different levels of goal congruence. A more detailed profile of supplier characteristics or competency domains and competency maturity (Correia et al., 2017) and internal organization design (e.g. type of formalization), and a more nuanced, multidimensional classification of their unique relational history with the buyer would have allowed us to better understand the root causes of suppliers' differential responses to the treatments.

Lastly, and most significantly, future studies should examine empirically different formalization interventions' effectiveness for behavioral change. The phased approach we chose for our field experiment - to initially assess the attitudinal impact of formalization at the buyer-supplier interface before undertaking a (planned) assessment of behavioral changes - is based on theories of reasoned action which suggest that attitudes predict behaviors (Ajzen \& Fishbein, 1977), and on empirical findings that indicate attitudes as an important aspect of readiness for change towards 
Organization Design and Supplier Engagement in Sustainability Programs

sustainable business practices (Lülfs \& Hahn, 2014). Indeed, the insurance firm's

recent changes in its supplier engagement efforts suggest that suppliers' relatively

positive attitudinal response to enabling formalization (and/or the lack of positive

response to the coercive formalization) can galvanize a buyer's efforts to further

stimulate and support behavioral change in its supply chain - in part because positive

attitudinal responses reduce the perceived uncertainty of behavior change

interventions. However, the attitude-action link is not uncontested, especially in the context of pro-environmental behaviors (Kaiser, Oerke, \& Bogner, 2007; Ouellette \& Wood, 1998), nor is its strength easily foreseeable (Amel, Manning, Scott, \& Koger, 2017). At a minimum, the attitude-action link should be considered subject to situational and social influences (Kahle, 2013; Warner \& DeFleur, 1969). Hence, probing the behavioral effects of enabling formalization in a supply chain requires a study design with a long timeframe and substantial, sustained monitoring of the involved actors, their relationships, and their task environment. Suitable governance arrangements for such a long-term evaluation would warrant field experiments in their own right.

\section{REFERENCES}

Adler, P. S. \& Borys, B. 1996. Two types of bureaucracy: Enabling and coercive. Administrative Science Quarterly, 41(1): 61-89.

Adler, P. S. 1999. Building better bureaucracies. The Academy of Management Executive, 13(4): 36-47.

Ajzen, I. \& Fishbein, M. 1977. Attitude-behavior relations: A theoretical analysis and review of empirical research. Psychological bulletin, 84(5): 888.

Albers, S., Wohlgezogen, F., \& Zajac, E. J. 2016. Strategic alliance structures: An organization design perspective. Journal of Management, 42(3): 582-614.

Amel, E., Manning, C., Scott, B., \& Koger, S. 2017. Beyond the roots of human inaction: fostering collective effort toward ecosystem conservation. Science, 356(6335): 275-279.

Amengual, M., Distelhorst, G., \& Tobin, D. 2019. Global purchasing as labor regulation: the missing middle. Industrial and Labor Relations Review. 
Amui, L. B. L., Jabbour, C. J. C., de Sousa Jabbour, A. B. L., \& Kannan, D. 2017. Sustainability as a dynamic organizational capability: a systematic review and a future agenda toward a sustainable transition. Journal of Cleaner Production, 142: 308-322.

Argyris, C. 1957. Personality and Organization: The conflict between system and the individual. New York: Harper Row.

Burns, T. \& Stalker, G. M. 1961. The Management of Innovation. London: Tavistock.

Card, D. \& Krueger, A. B. 1994. Minimum Wages and Employment: A Case Study of the Fast-Food Industry in New Jersey and Pennsylvania. American Economic Review, 84(4): 772-793.

Chatterji, A. K., Findley, M., Jensen, N. M., Meier, S., \& Nielson, D. 2016. Field experiments in strategy research. Strategic Management Journal, 37(1): 116132.

Correia, E., Carvalho, H., Azevedo, S., \& Govindan, K. 2017. Maturity models in supply chain sustainability: A systematic literature review. Sustainability, 9(1): 64.

Cunningham, C. E., Woodward, C. A., Shannon, H. S., MacIntosh, J., Lendrum, B., Rosenbloom, D., \& Brown, J. 2002. Readiness for organizational change: A longitudinal study of workplace, psychological and behavioural correlates. Journal of Occupational and Organizational psychology, 75(4): 377-392.

Delmas, M. A. \& Aragon-Correa, J. A. 2016. Field experiments in corporate sustainability research: Testing strategies for behavior change in markets and organizations: SAGE Publications Sage CA: Los Angeles, CA.

Dyer, J. 2000. Collaborative advantage: Winning through extended enterprise supplier networks. New York: Oxford University Press.

Dyer, J. \& Nobeoka, K. 2000. Creating and managing a high-performance knowledge-sharing network: the Toyota case. Strategic Management Journal, 21(3): 345-367.

Egels-Zandén, N. 2014. Revisiting supplier compliance with MNC codes of conduct: Recoupling policy and practice at Chinese toy suppliers. Journal of Business Ethics, 119(1): 59-75.

Foerstl, K., Azadegan, A., Leppelt, T., \& Hartmann, E. 2015. Drivers of supplier sustainability: Moving beyond compliance to commitment. Journal of Supply Chain Management, 51(1): 67-92.

Formentini, M. \& Taticchi, P. 2016. Corporate sustainability approaches and governance mechanisms in sustainable supply chain management. Journal of Cleaner Production, 112: 1920-1933.

Francis, R. G. \& Stone, R. C. 1956. Service and Procedures in Bureaucracy: A Case Study: University of Minnesota Press.

Galbraith, J. R. 1974. Organization design: An information processing view. Interfaces, 4(3): 28-36.

Gimenez, C. \& Sierra, V. 2013. Sustainable supply chains: Governance mechanisms to greening suppliers. Journal of business ethics, 116(1): 189-203.

Gouldner, A. 1954. Patterns of industrial bureaucracy. New York: Free Press.

Govindan, K., Seuring, S., Zhu, Q., \& Azevedo, S. G. 2016. Accelerating the transition towards sustainability dynamics into supply chain relationship management and governance structures. Journal of Cleaner Production, 112: 1813-1823. 
Gruman, J. A. \& Saks, A. M. 2011. Performance management and employee engagement. Human resource management review, 21(2): 123-136.

Gualandris, J., Klassen, R. D., Vachon, S., \& Kalchschmidt, M. 2015. Sustainable evaluation and verification in supply chains: Aligning and leveraging accountability to stakeholders. Journal of Operations Management, 38: 1-13.

Gulati, R., Puranam, P., \& Tushman, M. 2012. Meta-organization design: Rethinking design in interorganizational and community contexts. Strategic Management Journal, 33(6): 571-586.

Gulati, R., Wohlgezogen, F., \& Zhelyazkov, P. 2012. The Two Facets of Collaboration: Cooperation and Coordination in Strategic Alliances. The Academy of Management Annals, 6(1): 531-583.

Hall, R. H. \& Tittle, C. R. 1966. A Note on Bureaucracy and Its" Correlates". American Journal of Sociology, 72(3): 267-272.

Harrison, G. W. \& List, J. A. 2004. Field experiments. Journal of Economic literature, 42(4): 1009-1055.

Kahle, L. R. 2013. Attitudes \& Social Adaptation: A Person-Situation Interaction Approach. New York: Pergamon.

Kahn, W. A. 1990. Psychological conditions of personal engagement and disengagement at work. Academy of management journal, 33(4): 692-724.

Kaiser, F. G., Oerke, B., \& Bogner, F. X. 2007. Behavior-based environmental attitude: Development of an instrument for adolescents. Journal of Environmental Psychology, 27(3): 242-251.

Keating, B., Quazi, A., Kriz, A., \& Coltman, T. 2008. In pursuit of a sustainable supply chain: insights from Westpac Banking Corporation. Supply Chain Management: An International Journal, 13(3): 175-179.

Labowitz, S. \& Baumann-Pauly, D. 2014. Business as usual is not an option. New York, NY: Center for Business and Human Rights, New York University Stern School of Business.

Large, R. O. \& Thomsen, C. G. 2011. Drivers of green supply management performance: Evidence from Germany. Journal of Purchasing and Supply Management, 17(3): 176-184.

Locke, R., Amengual, M., \& Mangla, A. 2009. Virtue out of necessity? Compliance, commitment, and the improvement of labor conditions in global supply chains. Politics \& Society, 37(3): 319-351.

Locke, R. M., Qin, F., \& Brause, A. 2007. Does monitoring improve labor standards? Lessons from Nike. ILR Review, 61(1): 3-31.

Lowitt, E. 2013. The Collaboration Economy: How to meet business, social, and environmental needs and gain competitive advantage. San Francisco, CA: Wiley.

Lülfs, R. \& Hahn, R. 2014. Sustainable behavior in the business sphere: A comprehensive overview of the explanatory power of psychological models. Organization \& Environment, 27(1): 43-64.

Macey, W. H. \& Schneider, B. 2008. The meaning of employee engagement. Industrial and organizational Psychology, 1(1): 3-30.

Matheson, C. 2007. In praise of bureaucracy? A dissent from Australia. Administration \& society, 39(2): 233-261.

Meyer, J. W. \& Rowan, B. 1977. Institutionalized Organizations: Formal Structure as Myth and Ceremony. The American Journal of Sociology, 83(2): 340-363.

Miller, G. 1967. Professionals in bureaucracy: Alienation among industrial scientists and engineers. American Sociological Review, 32: 775-767. 
Mintzberg, H. 1980. Structure in 5's - a synthesis of the research on organization design. Management Science, 26(3): 322-341.

Nock, S. L. \& Guterbock, T. M. 2010. Survey experiments. Handbook of survey research, 2: 837-865.

Ocasio, W. \& Wohlgezogen, F. 2010. Attention and control. In S. Sitkin, L. Cardinal, \& K. Bijlsma-Frankema (Eds.), Organizational Control: 191-221. Cambridge: Cambridge University Press.

Ouchi, W. G. 1979. A conceptual framework for the design of organizational control systems. Management Science, 25(9): 833-848.

Ouellette, J. A. \& Wood, W. 1998. Habit and intention in everyday life: The multiple processes by which past behavior predicts future behavior. Psychological bulletin, 124(1): 54.

Parmigiani, A., Klassen, R. D., \& Russo, M. V. 2011. Efficiency meets accountability: Performance implications of supply chain configuration, control, and capabilities. Journal of operations management, 29(3): 212-223.

Parsons, T. 1947. Introduction, Max Weber, The Theory of Social and Economic Organization: $3-86$. Glencoe, IL: Free Press.

Petty, R. E., Wegener, D. T., \& Fabrigar, L. R. 1997. Attitudes and attitude change. Annual review of psychology, 48(1): 609-647.

Plambeck, E. L. \& Taylor, T. A. 2015. Supplier evasion of a buyer's audit: Implications for motivating supplier social and environmental responsibility. Manufacturing \& Service Operations Management, 18(2): 184-197.

Raymond, C. M., Fazey, I., Reed, M. S., Stringer, L. C., Robinson, G. M., \& Evely, A. C. 2010. Integrating local and scientific knowledge for environmental management. Journal of environmental management, 91(8): 1766-1777.

Reuer, J. J. \& Devarakonda, S. V. 2016. Mechanisms of hybrid governance: Administrative committees in non-equity alliances. Academy of Management Journal, 59(2): 510-533.

Rigoni, B. \& Nelson, B. 2016. Do Employees Really Know What's Expected of Them?, Business Journal: Gallup.

Saks, A. M. 2006. Antecedents and consequences of employee engagement. Journal of managerial psychology, 21(7): 600-619.

Sancha, C., Gimenez, C., \& Sierra, V. 2016a. Achieving a socially responsible supply chain through assessment and collaboration. Journal of Cleaner Production, 112: 1934-1947.

Sancha, C., Wong, C. W., \& Thomsen, C. G. 2016b. Buyer-supplier relationships on environmental issues: a contingency perspective. Journal of Cleaner Production, 112: 1849-1860.

Seuring, S. \& Müller, M. 2008. From a literature review to a conceptual framework for sustainable supply chain management. Journal of cleaner production, 16(15): 1699-1710.

Sisco, C., Chorn, B., \& Pruzan-Jorgensen, P. M. 2015. Supply chain sustainability: A practical guide for continuous improvement (2nd ed.): United Nations Global Compact.

Sulkowski, A. J., Edwards, M., \& Freeman, R. E. 2018. Shake your stakeholder: Firms leading engagement to cocreate sustainable value. Organization $\&$ Environment, 31(3): 223-241.

Temby, O., Sandall, J., Cooksey, R., \& Hickey, G. M. 2017. Examining the role of trust and informal communication on mutual learning in government: the case 
of climate change policy in New York. Organization \& Environment, 30(1): 71-97.

Udy, S. H. 1959. "Bureaucracy" and "Rationality" in Weber's Organization Theory: An Empirical Study. American Sociological Review, 24(6): 791-795.

Van de Ven, A. H. 2007. Engaged scholarship: A guide for organizational and social research: Oxford University Press on Demand.

Van Weele, A. J. \& Van Raaij, E. M. 2014. The future of purchasing and supply management research: About relevance and rigor. Journal of Supply Chain Management, 50(1): 56-72.

Vanneste, B. S., Puranam, P., \& Kretschmer, T. 2014. Trust over time in exchange relationships: Meta-analysis and theory. Strategic Management Journal, 35(12): 1891-1902.

Vurro, C., Russo, A., \& Perrini, F. 2009. Shaping sustainable value chains: Network determinants of supply chain governance models. Journal of business ethics, 90(4): 607-621.

Warner, L. G. \& DeFleur, M. L. 1969. Attitude as an interactional concept: Social constraint and social distance as intervening variables between attitudes and action. American Sociological Review: 153-169.

Wilding, R., Wagner, B., Pilbeam, C., Alvarez, G., \& Wilson, H. 2012. The governance of supply networks: a systematic literature review. Supply Chain Management: an international journal.

Yu, X. 2008. Impacts of corporate code of conduct on labor standards: A case study of Reebok's athletic footwear supplier factory in China. Journal of Business Ethics, 81(3): 513-529.

Zaheer, A., McEvily, B., \& Perrone, V. 1998. Does trust matter? Exploring the effects of interorganizational and interpersonal trust on performance. Organization Science, 9(2): 141-159.

Zollo, M., Cennamo, C., \& Neumann, K. 2013. Beyond what and why: Understanding organizational evolution towards sustainable enterprise models. Organization \& Environment, 26(3): 241-259. 
Organization Design and Supplier Engagement in Sustainability Programs

\section{FIGURES AND TABLES}

Figure 1: Theorized causal model and hypotheses for empirical testing

organizational
design intervention psychological state engagement

attitude to administrative

system

attitude to

goals

attitude to buyer-supplier relationship behavioral engagement

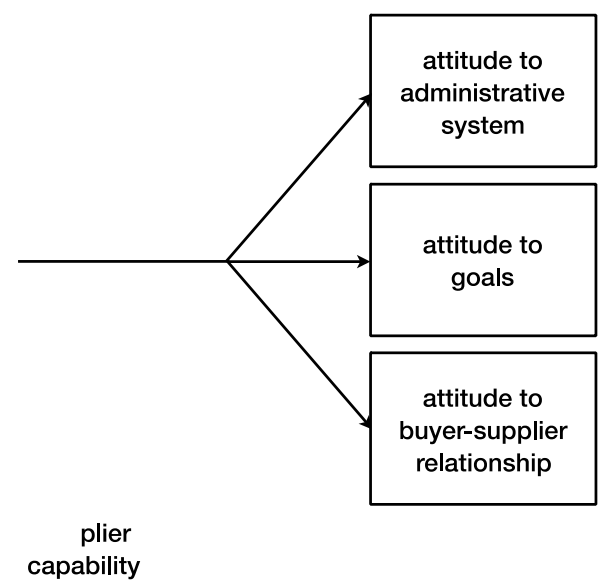

contingencies 
Table 1: Items for Baseline and Follow-up Supplier Survey

$\begin{array}{lll}\text { Category Items } & \text { Format }\end{array}$

\begin{tabular}{|c|c|c|c|}
\hline $\begin{array}{l}\text { Administrative } \\
\text { system }\end{array}$ & 1) & $\begin{array}{l}\text { A main benefit of formal rules and procedures } \\
\text { (e.g. codes of conduct, scorecards, reporting } \\
\text { forms, etc.) is... } \\
\text { - } \quad \text { opportunities for learning and change } \\
\text { - } \quad \text { problem solving in my organization } \\
\text { - control and supervision of suppliers } \\
\text { - alignment of activities among companies } \\
\quad \text { in the supply chain }\end{array}$ & forced ranking response \\
\hline Goals & 2) & $\begin{array}{l}\text { Environmental sustainability is important for } \\
\text { INSURER to be successful in the marketplace } \\
\text { INSURER values environmental sustainability }\end{array}$ & all 7-point Likert scale \\
\hline $\begin{array}{l}\text { Buyer-Supplier } \\
\text { Relationship }\end{array}$ & $\begin{array}{l}\text { 4) } \\
\text { 5) } \\
\text { 6) } \\
\text { 7) }\end{array}$ & $\begin{array}{l}\text { INSURER and my organization have a high } \\
\text { level of mutual trust } \\
\text { Members of my organization are able to bring } \\
\text { up problems and tough issues with INSURER } \\
\text { INSURER requires us to report detailed } \\
\text { information about our operations } \\
\text { INSURER uses formal guidelines and } \\
\text { procedures to evaluate our performance }\end{array}$ & all 7-point Likert scale \\
\hline Moderators & 8) & $\begin{array}{l}\text { In my organization, environmental } \\
\text { sustainability is a priority } \\
\text { How many OEM (Original Equipment } \\
\text { Manufacturers) approvals do you have? }\end{array}$ & $\begin{array}{l}\text { 7-point Likert scale } \\
\text { response options: none, } \\
\text { one, more than one }\end{array}$ \\
\hline Controls & $\begin{array}{l}\text { 10) } \\
\text { 11) } \\
\text { 12) }\end{array}$ & $\begin{array}{l}\text { Approximately how many vehicles does your } \\
\text { organization repair per year? } \\
\text { In my organization change initiatives are often } \\
\text { met with resistance (reverse coded) } \\
\text { Lessons learned from change initiatives are } \\
\text { routinely identified and shared in my } \\
\text { organization } \\
\text { In my organization people take initiative in } \\
\text { improving organizational performance }\end{array}$ & $\begin{array}{l}\text { number entry } \\
\text { 7-point Likert scale } \\
\text { 7-point Likert scale }\end{array}$ \\
\hline
\end{tabular}


Table 2: Pre-treatment differences between the treatment and control groups

\begin{tabular}{|c|c|c|c|c|c|c|c|c|c|c|c|c|}
\hline \multirow[b]{2}{*}{ Variable Name } & \multicolumn{3}{|c|}{ Full sample } & \multicolumn{3}{|c|}{ Enabling Condition } & \multicolumn{3}{|c|}{ Coercive Condition } & \multicolumn{3}{|c|}{ Control Condition } \\
\hline & Obs & Min & Max & Obs & Mean & Std. Dev. & Obs & Mean & Std. Dev. & Obs & Mean & Std. Dev. \\
\hline admin system benefit learning opportunity (ranked first) & 186 & 1 & 4 & 62 & 2.113 & 1.243 & 61 & 2.262 & 1.210 & 63 & 2.339 & 1.169 \\
\hline admin system benefit problem solving (ranked first) & 186 & 1 & 4 & 62 & 2.468 & 1.251 & 61 & 2.279 & 1.213 & 63 & 2.136 & 1.224 \\
\hline admin system benefit control (ranked first) & 186 & 1 & 4 & 62 & 2.048 & 1.179 & 61 & 2.361 & 1.239 & 63 & 2.356 & 1.171 \\
\hline admin system benefit alignment (ranked first) & 186 & 1 & 4 & 62 & 1.823 & 1.124 & 61 & 1.951 & 1.132 & 63 & 1.864 & 1.074 \\
\hline sustainability important for buyer success & 190 & 2 & 7 & 61 & 5.541 & 1.149 & 61 & 5.803 & 1.249 & 68 & 5.797 & 1.030 \\
\hline sustainability valued by buyer & 191 & 1 & 7 & 62 & 5.613 & 1.136 & 61 & 5.623 & 1.428 & 68 & 5.712 & 1.175 \\
\hline mutual trust & 187 & 1 & 7 & 63 & 6.000 & 1.295 & 61 & 5.967 & 1.483 & 63 & 6.169 & 0.950 \\
\hline supplier able to raise problems with buyer & 185 & 1 & 7 & 62 & 5.468 & 1.352 & 61 & 5.574 & 1.802 & 62 & 5.729 & 1.424 \\
\hline buyer requires detailed operational info & 184 & 1 & 7 & 61 & 5.820 & 1.103 & 61 & 5.377 & 1.572 & 62 & 6.017 & 0.938 \\
\hline buyer formally evaluates supplier performance & 196 & 1 & 7 & 64 & 5.797 & 1.224 & 63 & 5.698 & 1.387 & 65 & 5.908 & 0.996 \\
\hline firm size (vehicles repaired per year in 100s) & 192 & 1 & 36 & 63 & 9.729 & 7.300 & 61 & 11.941 & 7.589 & 68 & 9.137 & 5.983 \\
\hline readiness for change & 180 & 1 & 7 & 60 & 4.283 & 1.678 & 61 & 3.738 & 1.769 & 59 & 3.509 & 1.833 \\
\hline sustainability is priority for supplier & 190 & 2 & 7 & 62 & 5.645 & 0.925 & 61 & 5.639 & 1.212 & 67 & 5.845 & 1.121 \\
\hline OEM certification & 192 & 1 & 3 & 63 & 2.270 & 0.971 & 61 & 2.475 & 0.887 & 68 & 2.322 & 0.955 \\
\hline
\end{tabular}


Organization Design and Supplier Engagement in Sustainability Programs

Table 3: Differences-in-Differences Results for Enabling and Coercive Formalization Treatments

\begin{tabular}{|c|c|c|c|c|c|c|c|c|c|c|}
\hline & \multicolumn{5}{|c|}{ enabling formalization treatment } & \multicolumn{5}{|c|}{ coercive formalization treatment } \\
\hline & $\begin{array}{c}\text { Model } 1 \\
\text { full sample }\end{array}$ & $\begin{array}{c}\text { Model } 2 \\
\text { high goal } \\
\text { congruence } \\
\text { subsample }\end{array}$ & $\begin{array}{l}\text { Model } 3 \\
\text { low goal } \\
\text { congruence } \\
\text { subsample }\end{array}$ & $\begin{array}{c}\text { Model } 4 \\
\text { high capability } \\
\text { subsample }\end{array}$ & $\begin{array}{c}\text { Model } 5 \\
\text { low capability } \\
\text { subsample }\end{array}$ & $\begin{array}{l}\text { Model } 6 \\
\text { full sample }\end{array}$ & $\begin{array}{c}\text { Model } 7 \\
\text { high goal } \\
\text { congruence } \\
\text { subsample }\end{array}$ & $\begin{array}{c}\text { Model } 8 \\
\text { low goal } \\
\text { congruence } \\
\text { subsample }\end{array}$ & $\begin{array}{c}\text { Model } 9 \\
\text { high capability } \\
\text { subsample }\end{array}$ & $\begin{array}{c}\text { Model } 9 \\
\text { low capability } \\
\text { subsample }\end{array}$ \\
\hline \multicolumn{11}{|l|}{ administrative system } \\
\hline learning opportunity & $\begin{array}{l}1.6191{ }^{* *} \\
{[0.8091]}\end{array}$ & $\begin{array}{r}2.4188 \\
{[1.6028]}\end{array}$ & $\begin{array}{r}1.3298 \\
{[0.8969]}\end{array}$ & $\begin{array}{l}2.8462 * * \\
{[1.0968]}\end{array}$ & $\begin{array}{r}0.7497 \\
{[1.8221]}\end{array}$ & $\begin{array}{r}0.9801 \\
{[0.6867]}\end{array}$ & $\begin{array}{r}2.2238 \\
{[1.4159]}\end{array}$ & $\begin{array}{r}-0.1498 \\
{[0.8229]}\end{array}$ & $\begin{array}{r}1.1438 \\
{[0.9993]}\end{array}$ & $\begin{array}{r}1.1438 \\
{[0.9993]}\end{array}$ \\
\hline problem solving & $\begin{array}{l}-1.6064 * * \\
{[0.7347]}\end{array}$ & $\begin{array}{l}-2.6052 * \\
{[1.3525]}\end{array}$ & $\begin{array}{r}-0.7325 \\
{[0.9474]}\end{array}$ & $\begin{array}{l}-2.5005 * * \\
{[1.093]}\end{array}$ & $\begin{array}{r}-1.1036 \\
{[1.2779]}\end{array}$ & $\begin{array}{r}-0.0729 \\
{[0.723]}\end{array}$ & $\begin{array}{r}-0.7569 \\
{[1.3102]}\end{array}$ & $\begin{array}{r}1.0606 \\
{[0.9058]}\end{array}$ & $\begin{array}{r}-0.6037 \\
{[0.9263]}\end{array}$ & $\begin{array}{r}-0.6037 \\
{[0.9263]}\end{array}$ \\
\hline control and supervision of suppliers & $\begin{array}{r}0.1256 \\
{[0.7293]}\end{array}$ & $\begin{array}{r}1.2623 \\
{[1.5598]}\end{array}$ & $\begin{array}{r}0.0588 \\
{[0.9207]}\end{array}$ & $\begin{array}{r}0.1602 \\
{[1.0355]}\end{array}$ & $\begin{array}{r}0.4012 \\
{[1.2244]}\end{array}$ & $\begin{array}{l}-1.5512 * \\
{[0.7869]}\end{array}$ & $\begin{array}{r}-1.3495 \\
{[1.0819]}\end{array}$ & $\begin{array}{r}-1.4607 \\
{[1.1846]}\end{array}$ & $\begin{array}{r}-1.4231 \\
{[1.036]}\end{array}$ & $\begin{array}{r}-1.4231 \\
{[1.036]}\end{array}$ \\
\hline supply chain alignment & $\begin{array}{r}-0.903 \\
{[1.0047]}\end{array}$ & $\begin{array}{r}-1.4008 \\
{[1.5671]}\end{array}$ & $\begin{array}{r}-0.5769 \\
{[1.4364]}\end{array}$ & $\begin{array}{r}-1.4623 \\
{[1.1893]}\end{array}$ & $\begin{array}{l}14.9611 \\
{[2.9173]}\end{array}$ & $\begin{array}{r}-0.1752 \\
{[0.8715]}\end{array}$ & (a) & $\begin{array}{r}-0.2256 \\
{[1.2347]}\end{array}$ & $\begin{array}{r}0.6228 \\
{[1.115]}\end{array}$ & $\begin{array}{l}0.6228 \\
{[1.115]}\end{array}$ \\
\hline $\begin{array}{l}\text { importance of associated goals } \\
\text { sustainability valued by buyer }\end{array}$ & $\begin{array}{l}1.1511 * * \\
{[0.5017]}\end{array}$ & $\begin{array}{r}0.8018 \\
{[1.0158]}\end{array}$ & $\begin{array}{l}1.778 * * \\
{[0.73]}\end{array}$ & $\begin{array}{r}1.0379 \\
{[0.6512]}\end{array}$ & $\begin{array}{r}1.1968 \\
{[1.0541]}\end{array}$ & $\begin{array}{r}0.1137 \\
{[0.5213]}\end{array}$ & $\begin{array}{r}-0.6676 \\
{[1.0423]}\end{array}$ & $\begin{array}{r}1.1929 \\
{[0.8213]}\end{array}$ & $\begin{array}{r}0.0007 \\
{[0.6647]}\end{array}$ & $\begin{array}{r}1.0203 \\
{[1.1233]}\end{array}$ \\
\hline sustainability important for buyer success & $\begin{array}{r}0.7161 \\
{[0.5131]}\end{array}$ & $\begin{array}{r}0.3459 \\
{[0.9976]}\end{array}$ & $\begin{array}{c}1.2718 * \\
{[0.6957]}\end{array}$ & $\begin{array}{r}0.1667 \\
{[0.6949]}\end{array}$ & $\begin{array}{c}1.5479 * \\
{[0.8768]}\end{array}$ & $\begin{array}{r}0.6222 \\
{[0.5084]}\end{array}$ & $\begin{array}{r}-0.4593 \\
{[1.1115]}\end{array}$ & $\begin{array}{rl}1.6001 & * * \\
{[0.7198]} & \end{array}$ & $\begin{array}{r}0.5688 \\
{[0.6418]}\end{array}$ & $\begin{array}{r}1.0121 \\
{[1.4198]}\end{array}$ \\
\hline \multicolumn{11}{|l|}{ buyer-supplier relationship } \\
\hline comfortable raising problems with buyer & $\begin{array}{r}0.1708 \\
{[0.5444]}\end{array}$ & $\begin{array}{r}-0.636 \\
{[0.8685]}\end{array}$ & $\begin{array}{r}1.276 \\
{[0.9064]}\end{array}$ & $\begin{array}{r}0.6814 \\
{[0.7351]}\end{array}$ & $\begin{array}{r}-1.2367 \\
{[1.8]}\end{array}$ & $\begin{array}{r}-0.5749 \\
{[0.5245]}\end{array}$ & $\begin{array}{r}-1.2557 \\
{[0.9205]}\end{array}$ & $\begin{array}{r}0.2788 \\
{[0.7925]}\end{array}$ & $\begin{array}{r}-0.1876 \\
{[0.6738]}\end{array}$ & $\begin{array}{l}-2.9986 * \\
{[1.6471]}\end{array}$ \\
\hline buyer requires detailed operational info & $\begin{array}{r}0.6442 \\
{[0.6073]}\end{array}$ & $\begin{array}{r}-0.6996 \\
{[0.9849]}\end{array}$ & $\begin{array}{c}1.9923 * * \\
{[0.8123]}\end{array}$ & $\begin{array}{r}0.7873 \\
{[0.7482]}\end{array}$ & $\begin{array}{r}0.2327 \\
{[1.2754]}\end{array}$ & $\begin{array}{c}1.3818 * * \\
{[0.5367]}\end{array}$ & $\begin{array}{c}0.0591 \\
{[0.781]}\end{array}$ & $\begin{array}{l}2.8328 * * * \\
{[0.8605]}\end{array}$ & $\begin{array}{l}1.8958 * * * \\
{[0.6835]}\end{array}$ & $\begin{array}{r}-0.8654 \\
{[1.4437]}\end{array}$ \\
\hline buyer formally evaluates supplier & $\begin{array}{r}0.572 \\
{[0.5457]}\end{array}$ & $\begin{array}{r}0.5095 \\
{[1.0123]}\end{array}$ & $\begin{array}{r}0.722 \\
{[0.7507]}\end{array}$ & $\begin{array}{c}1.181 \text { * } \\
{[0.6009]}\end{array}$ & $\begin{array}{r}-1.0463 \\
{[1.4211]}\end{array}$ & $\begin{array}{r}0.4013 \\
{[0.5420]}\end{array}$ & $\begin{array}{r}-0.629 \\
{[1.0485]}\end{array}$ & $\begin{array}{r}1.0081 \\
{[0.7125]}\end{array}$ & $\begin{array}{r}1.0534 \\
{[0.6745]}\end{array}$ & (b) \\
\hline $\mathrm{N}$ & 180 & 87 & 106 & 130 & 63 & 180 & 96 & 100 & 144 & 45 \\
\hline
\end{tabular}




\section{APPENDIX 1}

\section{"enabling bureaucracy" environmental practices survey}

Environmental issues are becoming increasingly important for all businesses, and [INSURER] is committed to improving the overall environmental footprint of its supply chain.

The purpose of this part of the survey is to ELICIT YOUR VIEWS AND

SUGGESTIONS on environmental issues and practices in the MBR industry, and in your company.

1. In your opinion, which environmental issues or practices have the biggest environmental impact on your company at the moment?

2. How do you manage energy consumption in your company?

3. How would you evaluate your company's energy consumption? Do you see opportunities to improve it?

4. How do you think your company compares to the average level of energy consumption in the MBR industry?

5. How do you manage water consumption in your company?

6. How would you evaluate your company's water consumption? Do you see opportunities to improve it? How

7. How do you think your company compares to the average level of water consumption in the MBR industry?

8. How do you deal with solid and liquid waste (e.g. batteries, tires, glass, bumpers, oil, paint etc.)?

9. Are there ways in which your company could dispose of solid and liquid waste in a more environmentally sustainable way?

10. How do you deal with issues of air pollution (e.g. from spray operations, diesel generators, etc.)?

11. How would you evaluate your company's air pollution impact? Do you see opportunities to improve it? How do you think your company compares to the average level of air pollution in the MBR industry?

12. If your company had no financial constraints, which single initiative could your company undertake that would make the biggest positive contribution to environmental sustainability?

13. What are the biggest hurdles your company faces for improving its environmental practices?

\section{APPENDIX 2}

\section{“coercive bureaucracy" environmental practices survey}

Environmental issues are becoming increasingly important for all businesses, and [INSURER] is committed to improving the overall environmental footprint of its supply chain.

[INSURER] wants its suppliers to focus on the following categories of environmental impact: energy usage, water consumption, liquid waste, solid waste, and air pollution. 
The purpose of this reporting form is to RECORD YOUR COMPANY'S CURRENT ENVIRONMENTAL PRACTICES in these categories.

1. Which of the following categories has the biggest impact on your company's environmental sustainability?

[5 response options]

2. How much electricity (in kWh) did your company consume in the year 2014 ? [numerical input required]

3. Please evaluate your company's energy consumption relative to other firms in the MBR industry.

[5-point scale from "significantly below" to significantly above"]

4. How much water did your company consume in the year 2014 ? [numerical input required]

5. Please evaluate your company's water consumption relative to other firms in the MBR industry. [5-point scale from "significantly below" to significantly above"]

6. How do you dispose of the following solid and liquid waste? [5 response options for 8 material classes]

7. Please evaluate your company's handling of solid and liquid waste relative to other firms in the MBR industry.

[5-point scale from "significantly below" to significantly above"]

8. How many spray booths does your company operate? [numerical input required]

9. What environmental safeguard has your company implemented for its spray booths? [3 response options]

10. Please evaluate your company's handling of air pollution relative to other firms in the MBR industry. [5-point scale from "significantly below" to significantly above"]

11. If your company had no financial constraints, which single initiative could your company undertake to make that would make the biggest positive contribution to environmental sustainability? [5 response options]

12. What are the biggest hurdles your company faces for improving its environmental practices?

[5 response options] 


\section{University Library}

\section{- M M N E R VA A gateway to Melbourne's research publications}

Minerva Access is the Institutional Repository of The University of Melbourne

Author/s:

Wohlgezogen, F;Hofstetter, JS;Bruck, F;Hamann, R

Title:

Supplier Engagement in Sustainability Programs: A Field Experiment of Enabling Versus Coercive Formalization

Date:

2020-06-09

Citation:

Wohlgezogen, F., Hofstetter, J. S., Bruck, F. \& Hamann, R. (2020). Supplier Engagement in Sustainability Programs: A Field Experiment of Enabling Versus Coercive Formalization. ORGANIZATION \& ENVIRONMENT, 34 (3), pp.435-458. https:// doi.org/10.1177/1086026620921454.

Persistent Link:

http://hdl.handle.net/11343/260486 